\title{
ATTITUDE TOWARDS BORDER TOURISM AND ITS RELATIONSHIP WITH VISITOR SATISFACTION AND LOYALTY
}

\author{
Salvador MORAL-CUADRA \\ University of Córdoba, Faculty of Law and Economics and Business Sciences, \\ Puerta Nueva St., s/n, 14071, Córdoba, Spain, e-mail: salvador.moral@uco.es \\ Francisco ORGAZ-AGÜERA* \\ Technological University of Santiago, Salvador Estrella Sadhalá Av., s/n, 5100o, \\ Santiago de los Caballeros, Dominican Republic, e-mail: franorgaz@utesa.edu \\ Pablo M. CAÑERO-MORALES \\ University of Córdoba, Faculty of Law and Economics and Business Sciences, \\ Puerta Nueva St., s/n, 14071, Córdoba, Spain, e-mail: u72camop@uco.es
}

\begin{abstract}
Citation: Moral-Cuadra, S., Orgaz-Agüera, F., \& Cañero-Morales, P.M. (2019). ATTITUDE TOWARDS BORDER TOURISM AND ITS RELATIONSHIP WITH VISITOR SATISFACTION AND LOYALTY. GeoJournal of Tourism and Geosites, 25(2), 609-622. https://doi.org/10.30892/gtg.25226-384

Abstract: This study proposes new knowledge about tourism developed in border areas. In this study, structural equations models based on variance are applied, with a sample of 583 tourists. The study was conducted on the northern border of the Dominican Republic and Haiti. The results show that there is a positive influence of the attitudes of tourists in the value they perceive in the border destination, in their satisfaction with the destination and in the loyalty they have towards the place. It has been observed a positive influence of the value perceived by border visitors with satisfaction and loyalty.
\end{abstract}

Key words: border tourism; attitudes; satisfaction; perceived value; loyalty

\section{INTRODUCTION}

All economic sectors are subjected to globalization, which makes them be in continuous change. Tourist activity, one of the main sectors at a national level, is not an exception as far as employment is concerned and regarding the foreign exchange market. Following the data given by the World Tourism Organization (UNWTO, 2017), tourism contributes $10 \%$ of the global Gross Domestic Product. The continuous change that tourism is suffering is related to the new needs experienced by tourists, changing their behavior patterns and motivations, in search of new experiences.

\footnotetext{
* Corresponding author
} 
Thus, new tourist typologies emerge, which try to respond to these motivations, conforming new tourism products capable of attracting a tourist demand of their own and generating a complementary offer in the destination. This is why border tourism emerges (Jimber et al., 2017; Rogerson \& Rogerson, 2019).

The definition of border tourism has several previous implicit concepts that are basic for the understanding of how this kind of tourism is conceived. Lacoste (1993) defines border as that line of separation and contact between two or more states, where the existence of a discontinuity between the spaces of each country is manifested, not only due to territoriality, but also due to cultural, religious or other kinds of references. These limits are conceived as symbols of identity by antonomasia (Campos-Delgado \& OdgersOrtíz, 2012), so the borders are formed as a point of interaction and encounter (Newman, 2006). Regarding the concept of border, Sofield (2006) distinguishes between a delimitation of a legal nature and a cultural nature, since, as mentioned by Hageman et al. (2004), borders have been conceived as institutions that serve to mark functioning barriers between states, to impose control over the flow of people, to regulate crossborder trade or to indicate the platform and facilitate contact and exchange.

Bringas-Rábago (2004) defines border tourism as the temporary movement of people away from their place of habitual residence to the cities or zones adjacent to the dividing line between two countries, originated for reasons of leisure, fun, rest, health, business, visits to relatives and/or friends, religion, social events or purchases, among others, whose stay can last between a night and a year. In short, border tourism is the temporary displacement that implies, at least, an overnight stay in areas contiguous to the dividing line between countries, for different reasons of leisure, where activities related to tourism activity are carried out. The temporality of border tourism has been subject to criticism, since Valenzuela (2003) establishes that, to be identified as border tourists, the stay must last between 24 to 72 hours in the destination.

Nevertheless, this position is evidenced by other studies (Bringas \& González, 2003) that argue that a large number of tourists do not stay at the destination 24 hours, although in their stay they carry out tourist behavior (Gallegos \& López-López, 2004). The development of tourism activities in border areas between countries is closely related to the concept of cross-border cooperation (Studzieniecki et al., 2016), which is defined as an institutionalized collaboration between authorities of a subnational nature that are contiguous through the national borders (Perkmann, 2003). This conceptualization is an evolution of a previous definition given by Schmitt-Egner (1998), who understands crossborder cooperation as the cross-border interaction between neighboring regions for the preservation, governance and development of a common living space, without the participation of its central authorities. These areas, which have a consistent flow of visitors, require deepening the perceptions and valuations of tourism demand, with the aim of establishing improvements in the border tourist offer. Among the variables to analyze, it is important to study attitudes, perceived value, satisfaction and loyalty, which are characteristics that must be taken into account to know the behavior of visitors.

The aim of this study is to empirically compare the relationship between attitudes towards border tourism and the value, satisfaction and loyalty perceived by visitors who arrive at the border. The fieldwork of this research has been carried out on the northern border of the Dominican Republic and Haiti, which is the main passage point by land between these two countries (Jimber et al., 2017). This subject of investigation is pertinent because there are few notorious studies about this tourist typology. In addition, this study is relevant because it seeks empirical evidence on issues addressed for other tourism typologies, but not analyzed in border visitors. In this way, the fact that the Dominican Republic is a consolidated country in sun and beach tourism should 
be taken into consideration, even if it does different complementary activities, especially in relation to local culture and nature (Orgaz-Agüera \& López-Guzmán, 2015). For its part, the Republic of Haiti has many tourist resources, although it has not yet experienced major developments in tourist activity, highlighting sun and beach tourism and historical-cultural activities (Jimber et al., 2017). For both countries, border tourism is a formula to improve the management of tourist resources located on the border and, in addition, promote the sustainable development of local communities.

\section{LITERATURE REVIEW}

This research focuses on the attitudes of tourists, the value perceived by the tourist, tourist's satisfaction and their loyalty. Accordingly, the review of the literature has been divided into several sub-sections, which in turn delve into the components of the research.

\section{Value perceived by the tourist}

The value perceived by the consumer of a certain product or service has been deeply investigated in recent decades (Williams \& Soutar, 2009). Chiu et al. (2014) establish that the value perceived by the client is produced through the analysis of the costs and benefits derived from the acquisition of tangible and intangible products, in combination with quality, price and service. The perceived value, from a tourist point of view, is divided into two groups: the first one, a functional value where quality and value for money are included; and, secondly, a symbolic value derived from social and emotional aspects (Chen \& $\mathrm{Hu}$, 2010). Information on the attitudes of stakeholders towards tourism is of particular importance for the sustainability of a given geographical area, because the destination managers must understand the values and perceptions of the local and visiting community clearly in order to integrate them into the decision-making process and encourage their participation in the tourism area (Nicholas et al., 2009). Thus, the perceived value is useful to explain the opinions of consumers and their subsequent reactions (Moliner et al., 2011).

Thus, attitudes can be established as determinants when developing certain tourism behaviors (Han \& Kim, 2010), positively influencing tourism attitudes on perceived value (Castellanos-Verdugo et al., 2016). The improvement of the quality of the local environment also increases the visual appeal for tourists visiting the geographical area, promoting the improvement of aesthetic, recreational values and the residents and visitor's quality of life (Zhang \& Lai, 2012). Consequently, we propose that: H1: The attitude of the tourist positively influences the value perceived by the tourist in the destination.

\section{Tourist satisfaction}

Applied to tourism, satisfaction is understood as a mental and emotional state of the tourist after a given experience (Williams \& Soutar, 2009), that is, a psychological result that is derived from the lived experience (Lee et al., 2007). Oviedo-García et al. (2016) place the satisfaction as an important and relevant element for the survival of tourist companies. The existing literature on tourist satisfaction is abundant (Gursoy et al., 2007; Chi \& Qu, 2008; Mason \& Navasierra, 2013). Studies in which tourist satisfaction is shown exist in different contexts: purchases (Yüksel \& Yüksel, 2007), travel agencies (Millán \& Esteban, 2004) or wild refuges (Tian-Cole et al., 2002). Several authors (Ryu et al., 2008; Bajs, 2015) have analyzed the different effects of perceived value in relation to satisfaction, considering it as the best antecedent of satisfaction, since it has a positive effect on the satisfaction in the tourism field (Williams \& Soutar, 2009; Prebensen et al., 2014; Mohd-Any et al., 2015). The scientific literature also highlights the existence of a relationship between the tourist's attitude and satisfaction (Hernández-Maestro et al., 2006; Oviedo et al., 2016). Consequently, we propose that: H2: The attitude of the tourist positively influences the tourist's satisfaction; and H3: The value perceived by the tourist positively influences the tourist's satisfaction. 


\section{Tourist Loyalty}

Loyalty is understood as a preference to visit a certain destination with an intention to revisit it or to recommend it (Chi \& Qu, 2008; Boo et al., 2009; Pike et al., 2010). Loyalty has been conceptualized and related to marketing, understanding it as a result of satisfaction (Mattila, 2001). Chen and Tsai (2007) identify different degrees of loyalty regarding a given destination, distinguishing between the intentions of recommending a visited destination (Word of Mouth) and the intentions of revisiting this place (behavioral intentions). The Word of Mouth is the main indicator of loyalty in the purchase intention of a certain product or service (Rundle-Thiele, 2005).

Different authors (Chen \& Tsai, 2007; Lee et al., 2007; Chi \& Qu, 2008; Lee, 2009; Chi, 2011; Lee et al., 2011; Prayag \& Ryan, 2012) have addressed tourism-focused studies, which analyze the behavioral intentions and intentions of recommending destination. Some studies (Chen \& Tsai, 2007; Chi \& Qu, 2008; Ekinci et al., 2013) establish satisfaction and quality as antecedents of loyalty, as satisfaction is decisive from a certain tourist point for generating loyalty towards a destination (Alexandris et al., 2006).

Satisfaction, as well as other variables such as perceived value or quality of service, has been positioned as the most important antecedents that affect tourists' loyalty (Baker \& Crompton, 2000; Petrick, 2004). Similarly, several authors (Williams \& Soutar, 2009; Prebensen et al., 2016) consider the perceived value along with satisfaction as a direct antecedent in making behavioral and recommendation decisions.

Attitudes of tourists are then understood as determinants of the behavioral intentions of visitors (Wurzinger \& Johansson, 2006; Han \& Kim, 2010), directly affecting tourists' loyalty. As a result of what has been argued, we propose that: $\mathrm{H}_{4}$ : The attitude of the tourist positively influences the tourist's loyalty; H5: The value perceived by the tourist positively influences the tourist's loyalty; and H6: The satisfaction of the tourist positively influences the tourist's loyalty. There are studies that have worked with these hypotheses, although the set of hypotheses raised in the model have not been studied for border tourism, where there are special characteristics due to the diversity of existing cultures and products belonging to different countries. In this way, the model proposed can generate very useful data on the perceptions of border tourists and this, in turn, will encourage the development of more specific strategies and actions to improve border tourism between the Dominican Republic and the Republic of Haiti.

\section{RESEARCH METHODOLOGY}

Sample

The population of this study consists on tourists who have visited the northern border between the Dominican Republic and the Republic of Haiti, passing through the Dominican town of Dajabon and the Haitian town of Juana Mendez. It should be noted that there is no database that confirms the number of tourists visiting the border, so it has not been possible to establish a target population, as has already occurred in a previous research conducted in this destination (Orgaz-Agüera \& López-Guzmán, 2015). The lack of a target population led to the establishment of a sample size of about 600 surveys. The fieldwork was carried out between the months of July and September 2015, during which a total of 610 questionnaires were obtained. Nevertheless, only 583 were valid, which places the total number very closely to the originally planned sample size.

The questionnaire that was provided to the tourists was properly structured and translated into three languages (Spanish, English and French) to achieve the widest possible scope. It was applied anonymously. In addition, pollsters trained for the purpose of the research constantly supported the people who were surveyed. The survey respondents were selected randomly; for this, the pollsters were located in the border 
crossing between both countries, but in the Dominican Republic territory, and only those tourists who travelled from one country to another for tourism and leisure reasons were contacted. In order to discern this detail, an interview was planned for the visitor. Said interview provided a means to indicate if the reason for their trip was tourism and, in turn, if this tourist trip was going to take place in the border area.

All those visitors crossing the border but going to destinations far from the border, were discarded. The sociodemographic profile of the tourists who visited the Dominican-Haitian northern border is presented in Table 1.

Table 1. Sociodemographic profile

\begin{tabular}{|c|c|c|c|}
\hline Items & (\%) & Items & (\%) \\
\hline $\begin{array}{c}\text { Gender }(\mathrm{n}=571) \\
\text { Male } \\
\text { Female }\end{array}$ & $\begin{array}{l}52.5 \\
47.5\end{array}$ & $\begin{array}{c}\text { Level of studies }(\mathrm{n}=521) \\
\text { College or institute } \\
\text { Graduate } \\
\text { Master } \\
\text { Ph.D. }\end{array}$ & $\begin{array}{c}57.0 \\
34.5 \\
6.3 \\
2.1\end{array}$ \\
\hline $\begin{array}{c}\text { Civil status }(\mathrm{n}=531) \\
\text { Married } \\
\text { Single } \\
\end{array}$ & $\begin{array}{l}43.7 \\
56.3 \\
\end{array}$ & $\begin{array}{c}\text { Accommodation country }(\mathrm{n}=541) \\
\text { Dominican Republic } \\
\text { Haiti }\end{array}$ & $\begin{array}{l}84.3 \\
15.7 \\
\end{array}$ \\
\hline $\begin{array}{c}\text { Age (years) }(\mathrm{n}=532) \\
18-25 \\
26-34 \\
35-44 \\
45-54 \\
55-64 \\
+65 \\
\end{array}$ & $\begin{array}{l}23.7 \\
35 \cdot 5 \\
32.3 \\
6.0 \\
0.0 \\
2.4\end{array}$ & $\begin{array}{l}\text { Who accompanies you on the trip? } \\
\qquad(\mathrm{n}=525) \\
\text { Alone } \\
\text { Colleague or friends } \\
\text { Couple } \\
\text { Couple and childre }\end{array}$ & $\begin{array}{l}29.1 \\
45.5 \\
14.9 \\
10.5\end{array}$ \\
\hline $\begin{array}{c}\text { Country of origin }(\mathrm{n}=554) \\
\text { Dominican Republic } \\
\text { United States } \\
\text { Haiti } \\
\text { Mexico } \\
\text { Puerto Rico } \\
\text { Venezuela } \\
\text { Colombia } \\
\text { Argentina } \\
\text { Spain } \\
\text { Others }\end{array}$ & $\begin{array}{c}35.6 \\
24.7 \\
14.8 \\
6.1 \\
4.2 \\
3.1 \\
2.2 \\
1.6 \\
1.3 \\
6.4\end{array}$ & $\begin{array}{c}\text { First visit? }(\mathrm{n}=531) \\
\text { Yes } \\
\text { No }\end{array}$ & $\begin{array}{l}38.8 \\
61.2\end{array}$ \\
\hline
\end{tabular}

As a result of the data obtained from the previous table, the profile of the tourist visiting the Dominican-Haitian northern border consists of single men, between 26 and 44 years of age in almost $68 \%$ of the cases, mostly with a Dominican nationality (35.6\%), American (24.7\%), Haitian (14.8\%) and Mexican (6.1\%). Nevertheless, if tourists from the island are removed, the profile varies, and places Americans as those who visit the border the most (49.8\%), followed by Mexicans (12.4\%) and Puerto Ricans (8.4\%).

The works carried out by tourists are mostly carried out on their own in $41.3 \%$ of the cases. Another important percentage is that of the students (29.4\%), which relates to the fact that $23.7 \%$ of tourists are between 18 and 25 years old. The level of studies in more than half of the cases (57\%) is bachelor or lower, with few cases with postgraduate studies (Master 6.3\% and Ph.D 2.1\%). The vast majority of respondents said that they stay in the Dominican Republic (84.3\%). Almost half of the cases are traveling (45.5\%) with colleagues or friends. In $61.2 \%$ of the cases surveyed, people were not doing their first visit, and $33 \%$ of the respondents spent 2 days and 1 night. It is interesting that, if the cases where the respondents are Dominicans or Haitians are removed, the range of 
responses that makes reference to the previous presence in the place is considerably reduced, going from $38.8 \%$ to $48.8 \%$ in the case of those who have not previously been in the place, and from $61.2 \%$ to $51.2 \%$ in the case of those who had been there previously.

\section{Measurements}

In order to carry out the research, a duly structured questionnaire was carried out, collecting useful and pertinent information to achieve the objectives set forth in this investigation. The questionnaire was designed based on closed-ended questions. The formulation of the different items included in the questionnaire was selected from previous research (Martín-Ruíz et al., 2010; Yoon et al., 2010; Gelbman \& Timothy, 2011, Zhang \& Lai, 2012; Sullivan et al., 2012), aiming to guarantee its validity.

Based on the different items included in the questionnaire, a triple validation was performed: In a first phase, the items from the previous investigations were obtained, and the survey was reviewed by a tourism expert researcher, who analyzed the proposed items for each composite; subsequently, the questionnaire was analyzed by an expert from the area under study, so that the validity of the items was checked twice. In a second phase, the translation of the different items from English to Spanish was performed, looking for the relevant adaptations so that it could be understood in a Spanish and Dominican context, thus avoiding erroneous interpretations by the tourists answering the questionnaire. Finally, in a third phase, a pre-test of 20 surveys was carried out to corroborate that the items were perfectly understood. Once the first questionnaire model was developed, the aforementioned pre-test was carried out in order to analyze aspects such as the correct selection of variables, as well as the quality of the statements, and the order and/or clarity of the instructions for the completion of the questionnaire. After carrying the pre-test out in the Dominican-Haitian border area, the respondents stated that they had not had any problems understanding the test since it was written in Spanish, English and French. It should be noted that, for the preparation of the questionnaire in Dominican language, it was applied to several students of the Master of Business Administration and Management of the Technological University of Santiago in the Dominican Republic, with the objective of validating the adapted items.

Regarding the questionnaire, it was divided into three sections: the first one examines the attitudes of tourists towards border tourism; in the second section, different aspects are evaluated, such as the value of the destination, satisfaction and loyalty towards said destination; and, in the third part, the sociodemographic aspects of tourists are addressed. In the first two sections of the questionnaire, the assessments are measured through a Likert Scale of 5 points, in which 1 is interpreted as "strongly disagree or not at all important" and 5 as "strongly agree or very important", interpreting the central value (3) as indifference when evaluating said item. The total number of items is 22.

\section{Data analysis techniques}

After the questionnaires were applied, the data was computerized, creating a database in Microsoft Excel for a further in-depth analysis through the statistical programs of IBM SPSS 24.0 for the descriptive analysis, the analysis of reliability using the Cronbach Alpha and the analysis of means, and of SmartPLS 3 (PLS: Partial Least Squares), to proceed with the analysis of the structural equations (SEM, Structural Equation Modeling). SEMs are characterized by two elements: the first of the elements refers to the evaluation regarding the relations of dependence, both multiple and crossed (Batista \& Coenders, 2000); and secondly, they are characterized by the degree they have to represent concepts that are not observed in the relationships, also taking into account the measurement error during the estimation process (Cea, 2002). In addition, SEMs have the advantage of analyzing relationships for each subset of variables, allowing a series of interrelationships between the different variables of the different groups (Chin, 1998). 
Concerning the PLS method, it is placed within the structural equation models, making it one of the most important tools of multivariate analysis, denominated as second-generation multivariate analysis (Fornell, 1982). The objective of this analysis is the connection between theory and data (Fornell, 1982). There are different models when proceeding with the estimation of structural models. Some are based on the analysis of covariance structures, used in statistical programs such as SPSS AMOS and LISREL, and others based on an analysis centered on variances, through the Partial least squares algorithm (PLS), where a principal component analysis is combined with a Path analysis (Barclay et al., 1995). One of the main objectives of the PLS refers to the explanation of the variances of the variables of endogenous nature, which makes it a reliable tool for the determination of the behavior of the variables. The difference between the aforementioned second-generation analysis compared to the first generation (factorial analysis, analysis of major components, among others) is that the former allows us to incorporate technical knowledge prior to practical analysis (Fornell, 1982). The estimation methods based on covariance (LISREL, AMOS, among others) are more suitable when they possess a solid theoretical knowledge, focused on the development and evaluation of the theory, although with a lower theoretical knowledge. For the purpose of predictive research, using the PLS technique is considered more convenient (Barclay et al., 1995).

In the case of the social sciences particularly, the use of the analysis through PLS offers a series of advantages (Long Range Planning, 2012). Firstly, the limited sample size makes the PLS analysis be considered as more appropriate, given the sample-type requirements of the method based on covariance. And, secondly, in various disciplines, such as strategic planning, marketing or information systems management, formative measures are used, which makes using the method based on covariance difficult.

One of the main reasons why the PLS analysis was used for this proceeding is that it can confirm if the initial theoretical concepts are measured correctly through the different variables observed, analyzing the validity and reliability. These properties are essential when measuring attitudes, predispositions or emotional responses, which are exposed to great subjectivity. Thus, although the measurement and structural parameters are estimated at the same time, a PLS model is analyzed and presented in two clearly differentiated stages (Barclay et al., 1995): the evaluation of the reliability and validity of the measurement model, and the evaluation of the structural model.

\section{DATA AND RESULTS ANALYSIS}

\section{Evaluation of the reliability and validity of the measurement model}

The present measurement model intends to analyze the theoretical relationships that are measured by the observable variables, analyzing the reliability of the different items or indicators that make up the composites, such as the reliability of the latter (Castellanos-Verdugo et al., 2016). Table 2 and 3 show mode A (perceived value, satisfaction and loyalty) and mode B (attitudes) composites respectively. For mode A composites, the following factorial loads are presented, which are all greater than 0.707 (Cepeda \& Roldán, 2004) except for one of them (SA3).

Nevertheless, it is accepted since this limit of 0.707 should not be so strict in initial stages, permitting lower loads. However, the load should never be, in any case, lower than 0.4 , so it should proceed to its elimination from the model (Hair et al., 2012). Thus, the commonality of the variable shows the variance of an observable variable explained by the composite, so all indicators have a commonality higher than 0.5 (50\%), except that of item SA3 that presents a commonality of 0.487 (48.7\%).

The reliability of the composites verifies the internal consistency of the observable variables, evaluating the rigor with which these observable variables measure the same 
composite (Cepeda \& Roldán, 2004). This reliability is measured through Cronbach's Alpha and the Composite Reliability (Werts et al., 1974). The use of Composite Reliability is more common, since according to some authors (Fornell \& Larcker, 1981; Barclay et al., 1995) this measure is not influenced by the number of items that the scale could have or, in other words, the Composite Reliability does not assume that all the indicators receive the same weighting (Chin, 1998). Dijkstra \& Henseler (2015) indicate that Composite Reliability is the only consistent measure of reliability. The Composite Reliability has to be above o.80 (Nunnally, 1978), in each and every one of the mode A composites (perceived value, satisfaction and loyalty). These measures (Cronbach's Alpha and Composite Reliability) do not apply to B-mode composites.

Table 2. Reliability and validity of the mode A composites

\begin{tabular}{|l|c|c|c|c|c|}
\hline & $\begin{array}{c}\text { Cronbach's } \\
\text { Alpha }\end{array}$ & $\begin{array}{c}\text { Composite } \\
\text { Reliability }\end{array}$ & AVE & Loading & Commonality \\
\hline $\begin{array}{l}\text { Perceived value } \\
\text { This destination offers more value than } \\
\text { expected } \\
\text { This destination offers me more value } \\
\text { than other border areas visited }\end{array}$ & 0.679 & 0.862 & 0.757 & 0.882 & 0.778 \\
\hline $\begin{array}{l}\text { Satisfaction } \\
\text { I am satisfied with the visit to the } \\
\text { Dominican-Haitian border }\end{array}$ & 0.638 & 0.804 & 0.579 & 0.814 & 0.663 \\
$\begin{array}{l}\text { I am happy to visit this border region } \\
\text { I am satisfied with my visit to the } \\
\text { Dominican Republic }\end{array}$ & & & & 0.766 & 0.587 \\
\hline $\begin{array}{l}\text { I will recomalty } \\
\text { friends and family } \\
\text { In the future, I will repeat the visit }\end{array}$ & 0.701 & 0.870 & 0.870 & 0.877 & 0.769 \\
\hline
\end{tabular}

Convergent validity implies that a set of observable variables presents a single underlying composite, explained due to its unidimensionality (Henseler et al., 2009). The convergent validity is measured through the Average Variance Extracted, providing the amount of variance that the composite obtained from its indicators, in relation to the amount of variance that is due to the measurement error (Cepeda \& Roldán, 2004). This variance should be greater than 0.5 (Fornell \& Larcker, 1981), which would imply that each composite would explain at least $50 \%$ of the variance of its observable variables. All the mode A composites present in the model satisfy this condition.

The discriminant validity indicates the extent to which a given composite is different from other composites (Cepeda \& Roldán, 2004). To measure this discriminant validity, two measures are used: Fornell criterion and Heterotrait-Monotrait ratio, which is a more demanding measure than the first one (Henseler, Hubona \& Ray, 2016).

For there to be discriminant validity using the Fornell criterion, the correlation between the different composites must be less than the square root of the AVE (Average Variance Extracted) (Barclay et al., 1995), while the ratio of Heterotrait-Monotrait has to present a ratio between composites of 0.85 (Clark \& Watson, 1995; Kline, 2011). However, other authors (Gold et al., 2001; Teo et al., 2008) place this ratio at 0.90, showing discriminant validity for the two measurements, according to what is shown in Table 4 . Mode B composites (attitudes) are studied through weights, and not charges used for the mode A composites (Chin, 1998). These weights report the importance of each indicator in the formation of their respective composite, indicating possible multicollinearity by various authors (Mathieson et al., 2001; Diamantopoulos \& Winklhofer, 2001) in the 
indicators of the B-mode composite. Variable Inflation Factor Test (VIF) corroborates the existence or not of this multicollinearity, assuming, following various authors (Mathieson et al., 2001; Diamantopoulos \& Winklhofer, 2001; Hair et al., 2014) values higher than VIF 5. This presents potential collinearity problems. Roberts and Thatcher (2009) propose a stricter criterion, placing the limit value of VIF for the existence of multicollinearity at 3.3. The position of Roberts and Thatcher (2009) has been chosen for this study and, as shown in Table 3, all the VIF values of the training indicators have values below 3.3, so it can be said that multicollinearity is not a limitation in this research.

Table 3. Reliability and validity of the mode B composites

\begin{tabular}{|l|c|c|}
\hline \multicolumn{1}{|c|}{ Attitudes } & Weight & VIF \\
\hline - Border tourism should be based on enjoying and appreciating the natural or & 0.197 & 1.331 \\
cultural characteristics of a destination & & \\
- The development of border tourism should focus on the local culture & 0.296 & 1.339 \\
- Border tourism encourages the participation of the population in this tourist activity & 0.377 & 1.473 \\
- Part of the income from border tourism should finance the conservation of & 0.220 & 1.174 \\
tourism resources of the border in the region & & \\
- Border tourism should encourage cooperation between bordering countries & 0.323 & 1.931 \\
\hline
\end{tabular}

Table 4. Discriminant validity. Fornell Criteria (Ratio Heterotrait-Monotrait)

\begin{tabular}{|c|c|c|c|c|}
\hline & Attitudes & Loyalty & Satisfaction & Perceived value \\
\hline Attitudes & & & & \\
\hline Loyalty & 0.365 & 0.877 & & \\
\hline Satisfaction & 0.416 & $0.571(0.843)$ & 0.761 & \\
\hline Perceived value & 0.234 & $0.483(0.698)$ & $0.466(0.691)$ & 0.870 \\
\hline
\end{tabular}

The valuation of the measurement model has turned out to be optimal as a result of the data obtained in Tables 2, 3 and 4, thus beginning the analysis of the structural model, which is initiated in the following section.

\section{Evaluation of the structural model}

Castellanos-Verdugo et al. (2016) point out that, in the structural models, the weights and the different magnitudes of the relationships between the different variables that make up the model are measured and evaluated.

Table 5. Contrast hypothesis via confidence intervals

\begin{tabular}{|l|c|c|c|c|}
\hline \multicolumn{1}{|c|}{ Hypothesis } & Path & \multicolumn{2}{c|}{ Intervals } & Is it \\
& coefficients & $\mathbf{5 \%}$ & $\mathbf{9 5 \%}$ & supported? \\
\hline $\mathrm{H} 1(+):$ Attitudes $\rightarrow$ Perceived value & $0.234^{\text {sig }}$ & 0.177 & 0.302 & Yes \\
\hline $\mathrm{H} 2(+):$ Attitudes $\rightarrow$ Satisfaction & $0.325^{\text {sig }}$ & 0.267 & 0.391 & Yes \\
\hline $\mathrm{H} 3(+):$ Perceived value $\rightarrow$ Satisfaction & $0.390^{\text {sig }}$ & 0.329 & 0.444 & Yes \\
\hline H4(+): Attitudes $\rightarrow$ Loyalty & $0.142^{\text {sig }}$ & 0.075 & 0.217 & Yes \\
\hline $\mathrm{H} 5(+):$ Perceived value $\rightarrow$ Loyalty & $0.270^{\text {sig }}$ & 0.206 & 0.336 & Yes \\
\hline H6(+): Satisfaction $\rightarrow$ Loyalty & $0.386^{\text {sig }}$ & 0.294 & 0.471 & Yes \\
\hline
\end{tabular}

Through a Bootstrapping of 5,000 subsamples, the stability of the estimates is examined, and it is not necessary for the sample to follow a normal distribution, as it should happen in the case of the CB-SEM (Hair et al., 2017). Since the measures are nonparametric (Barroso et al., 2010), the contrast is carried out by means of a hypothesis test based on confidence intervals, with a level of significance of 0.05. The Bootstrapping technique applied to PLS is a measure used for the exact estimation of the measurement model (Roldán \& Sánchez-Franco, 2012). The hypotheses to be completed in the contrast 
of the previous hypothesis are the ones presented in Table 5 contrasted by confidence intervals. The results obtained from the hypothesis test carried out using confidence intervals obtain identical results as if they were carried out through the test, as shown in Table 6. On the other hand, the amount of explained variance of each exogenous variable explained in relation to the endogenous variables is shown in Table 7.

Table 6. Hypotheses contrast via t test

\begin{tabular}{|c|c|c|c|c|}
\hline Hypothesis & $\begin{array}{c}\text { Path } \\
\text { coefficients }\end{array}$ & t values & p-limit & \begin{tabular}{|c|} 
Is it \\
supported?
\end{tabular} \\
\hline H1(+): Attitudes $\rightarrow$ Perceived value & $0.234^{* * *}$ & 6.160 & 0.000 & Yes \\
\hline $\mathrm{H} 2(+):$ Attitudes $\rightarrow$ Satisfaction & $0.325^{* * *}$ & 8.547 & 0.000 & Yes \\
\hline $\mathrm{H}_{3}(+):$ Perceived value $\rightarrow$ Satisfaction & $0.390^{* * *}$ & 10.834 & 0.000 & Yes \\
\hline $\mathrm{H} 4(+):$ Attitudes $\rightarrow$ Loyalty & $0.142^{* * *}$ & 3.258 & 0.001 & Yes \\
\hline $\mathrm{H}_{5}(+)$ : Perceived value $\rightarrow$ Loyalty & $0.270^{* * *}$ & 6.873 & & Yes \\
\hline H6(+): Satisfaction $\rightarrow$ Loyalty & $0.386^{* * *}$ & 7.154 & 0.000 & Yes \\
\hline
\end{tabular}

Table 7. Effect on endogenous variable

\begin{tabular}{|l|c|c|c|c|c|}
\hline & $\mathrm{R}^{2}$ & $\mathrm{Q}^{2}$ & Coefficient Path & Correlation & Explained variance (\%) \\
\hline $\begin{array}{l}\text { Perceived value } \\
\text { H1: Attitudes }\end{array}$ & 0.055 & 0.039 & 0.234 & 0.234 & $5.48 \%$ \\
\hline $\begin{array}{l}\text { Satisfaction } \\
\text { H2: Attitudes }\end{array}$ & 0.317 & 0.171 & $\begin{array}{l}0.325 \\
0.390\end{array}$ & $\begin{array}{l}0.416 \\
0.466\end{array}$ & $\begin{array}{l}13.52 \% \\
\text { H3: Perceived value }\end{array}$ \\
& & & & & $18.17 \%$ \\
\hline Loyalty & & 0.142 & 0.365 & $5.18 \%$ \\
H4: Attitudes & 0.402 & 0.290 & 0.270 & 0.483 & $13.04 \%$ \\
H5: Perceived value & & & 0.386 & 0.571 & $22.04 \%$ \\
H6: Satisfaction & & & & \\
\hline
\end{tabular}

After the data shown in Table 7, attitude explains $5.18 \%$ of the variance of loyalty, $13.52 \%$ of the satisfaction variance and $5.48 \%$ of the perceived value. The perceived value explains $13.04 \%$ of the variance of loyalty and $18.17 \%$ of satisfaction. The latter, satisfaction, explains $22.04 \%$ of the variance of loyalty. Regarding the predictive relevance (Geisser, 1975) of the composites dependent on the model, the $\mathrm{Q}^{2}$ of Stone-Geisser is used, which is positive in all cases $\left(\mathrm{Q}^{2}=0.290\right.$ for loyalty, $\mathrm{Q}^{2}=0.171$ for satisfaction, $\mathrm{Q}^{2}=$ o.039 for perceived value), so that the model presents sufficient predictive relevance in relation to each of its endogenous variables, because for there to be predictive relevance, $\mathrm{Q}^{2}$ must be greater than zero (Henseler et al., 2009). As it has been observed in the previous tables, there is a positive influence of the attitudes on the perceived value (H1). In the same way, attitudes have a positive influence on tourist satisfaction (H2) and on tourist loyalty (H4). Also, a positive influence of perceived value has been observed on tourist satisfaction $\left(\mathrm{H}_{3}\right)$ and tourist loyalty ( $\left.\mathrm{H}_{5}\right)$. Finally, that hypothesis that signaled a positive influence of tourist satisfaction on loyalty has also been supported (H6).

\section{CONCLUSION}

Tourism is one of the sectors with the highest growth, due to its multidisciplinary nature (López-Guzmán et al., 2018). It has experienced a considerable growth during the last decade in the number of tourists, income and employment derived from tourism activity, generating continuous interrelations between supply and demand. Tourism has not only been taken into account by developed countries but developing countries which increasingly see tourism as a socio-economic engine that creates jobs and currency movements. It has been demonstrated through studies that the economic growth and the 
reduction of the poverty is derived from tourist activities carried out in a given destination. In relation to border tourism, there is little scientific literature, and, for this reason, it is pertinent to address aspects related to it, especially in relation to the behavior of visitors.

Regarding the proposed model, the tests related to the reliability of the A-mode composites (Composite Reliability) are positive, since all the values obtained are above the minimum value required in each of the analyzed composite (value perceived by the tourist in the destination, satisfaction of the tourist in the destination and loyalty of the tourist towards the destination). As regards to the convergent validity and the discriminant validity, the results are also positive since there are no anomalous values. Regarding the predictive measures, each and every one of them are positive, both in the variance explained (R2), where all the values are above the minimum value $(>0.1)$ in each of the analyzed composite (attitude toward border tourism, value perceived by the tourist in the destination, satisfaction of the tourist in the destination and loyalty of the tourist towards the destination), as well as in the case of the Q2 redundancy ( $>0)$, where all the composites have values higher than zero, so it can be confirmed that each of the constructs inserted in the structural model have predictive relevance.

It has been proven that there is a positive influence of the attitudes of border tourists on the value perceived by them in the border destination. Similarly, it has been proven that the attitudes of border visitors have a positive influence on their satisfaction with the border destination and on the loyalty, they have towards the place. Also, a positive influence of the value perceived by the border visitors has been observed in the satisfaction of the border tourist and in their loyalty. Finally, it has been verified that there is a positive influence of border tourist satisfaction on their loyalty towards the destination of the border. All relationships have been low regarding the explanatory variance, although they provide relevant data to know the behavior of border visitors. These results can be very useful for different organizations belonging to each of the two countries that make up the border: on the one hand, for the Ministry of Tourism and the Ministry of Environment and Natural Resources of the Dominican Republic; on the other hand, for the Ministry of Tourism and Creative Industries and the Ministry of Agriculture, Natural Resources and Rural Development of the Republic of Haiti, with intentions of working on border promotion strategies and establishing companies in border areas in order to stimulate the area from an economic, social and a sustainable point of view, affecting the minimum environment where they are inserted.

The results obtained for the provincial border agencies may also be interesting, including the Administrations of the provinces of Montecristi, Dajabon, Elías Piña, Independencia and Pedernales by the Dominican Republic, and the provinces Northeast, Center, West and Southeast in the case of the Republic of Haiti. It should be noted that the managers of the existing resources in the border limits, whether public or private entities, have to work for the sustainable development of the area, generating jobs that go mostly to the local community. In addition, the development of corporate social responsibility has to be supported, in favor of improving employees' education, as well as of local communities, as this will generate an increase in value and perceived quality, and the satisfaction of visitors. Thus, efforts must be made by public and private entities for the controlled increase of accommodation places in the border area, as well as other services, in order to retain tourists in these areas, to generate a tourism offer that, added to the potential border resources mentioned above, generate a consistent offer. They can increase the number of tourists and, therefore, the income derived from the activity, provided it is done from a sustainable and responsible point of view. It should also be noted that this work is limited by the fact that only direct relationships can be demonstrated, without examining the mediating or moderating roles of other variables. Thus, future research should verify the 
relationship between the different variables of this study, applying this questionnaire in other national and international border areas, and verifying the relationship of mediation and moderation of some variables with age, gender or nationality. In turn, the motivations of tourists visiting the border should be analyzed and these motivations should be related to the perceived value, satisfaction and loyalty of the visitor.

\section{REFERENCES}

Alexandris, K., Kouthouris, C., \& Meligdis, A. (2006). Increasing customers' loyalty in a skiing resort: The contribution of place attachment and service quality. International Journal of Contemporary Hospitality Management, vol. $18, \mathrm{n}^{0}$ 4, p. 414-425.

Bajs, I. P. (2015). Tourist perceived value, relationship to satisfaction, and behavioral intentions: the example of the Croatian tourist destination Dubrovnik. Journal of Travel Research, 54(1), 122-134.

Baker, D. A., \& Crompton, J. L. (2000). Quality, satisfaction and behavioral intentions. Annals of Tourism Research, 27(3), 785-804.

Barclay, D., Higgins, C., \& Thompson, R. (1995). The partial least squares (PLS) approach to casual modeling: personal computer adoption and use as a 356 illustration. Technology Studies, Special Issue on Research Methodology, 2(2), 285-309.

Barroso, C., Cepeda, G., \& Roldán, J.L. (2010). Applying Maximum Likelihood and PLS on different simple sizes: Studies on SERVQUAL Model and employee behavior Model. In Esposito, V., Chin, W.W., Henseler, J., y Wang, H. (Eds): Handbook of Partial Least Squares Concepts, Methods and Application (pp. 427-447). Springer Handbooks of Computational Statistics.

Batista, J., \& Coenders G. (2000). Modelos de ecuaciones estructurales. Madrid: La Muralla.

Boo, S., Busser, J., \& Baloglu, S. (2009). A model of customer-based brand equity and its application to multiple destinations. Tourism Management, 3o(2), 219-231.

Bringas Rábago, N. (2004). Turismo fronterizo: caracterización y posibilidades de desarrollo. Tijuana, México: COLEF-CESTUR.

Bringas Rábago, N., \& González Aguirre. J.I.I. (2003). Algunos aspectos sobre el turismo en la frontera norte de México. In Por las Fronteras del Norte. Una aproximación cultural a la frontera México-Estados Unidos (pp. 272-301). México: Consejo Nacional para la Cultura y las Artes-El Colegio de la Frontera Norte.

Campos Delgado, A., \& Odgers Ortíz, O. (2012). Crossing the border: moblility as a resource in the Tijuana/San Diego and Tecún Umán/Tapachula regions. Estudios Fronterizos, 13(26), 9-32.

Castellanos Verdugo, M., Vega Vázquez, M., Oviedo García, M.A., \& Orgaz Agüera, F. (2016). The relevance of phychological factors in the ecotourist experience satisfaction through ecotourist site perceived value. Journal of Cleaner Production, 124, 226-235.

Cea M. (2002) Analysis multivariable. Teoría y práctica en la investigación social. Madrid: Síntesis.

Cepeda Carrión, G., \& Roldán Salgueiro, J.L. (2004). Aplicando la técnica PLS en la Administracción de Empresas. In XIV Congreso ACEDE Conocimiento y Competitividad. Septiembre. Murcia.

Chen, P., \& Hu, H. (2010). The Effect of Relational Benefits on Perceived Value in Relation to Customer Loyalty: An Empirical Study in the Australian Coffee Outlets Industry. International Journal of Hospitality Management, 29(3), 405-412.7

Chen, C.-F., \& Tsai, D. (2007). How destination image and evaluative factors affect behavioral intentions? Tourism Management, 28(4), 1115-1122.

Chi, C.G.Q. (2011). Destination loyalty formation and travelers' demographic characteristics: A multiple group analysis approach. Journal of Hospitality and Tourism Research, 35(2), 191-212.

Chi, C.G.Q. \& Qu, H. (2008). Examining the structural relationships of a destination image, tourist satisfaction and destination loyalty. An integrated approach. Tourism Management, 29(4), 624-636.

Chin, W.W. (1998). The partial least squares approach to structural equation modeling. In Marcoulides, G.A.: Modern Methods for Business Research (pp. 295-336). Mahwah, N.J.: Lawrece Erlbaum Associates, Publisher.

Chiu, Y., Lee, W., \& Chen, T. (2014). Environmentally Responsible Behavior in Ecotourism. Antecedents and Implications. Tourism Management, 40, 321-329.

Clark, L.A., \& Watson, D. (1995). Constructing validity: basic issues in objective scale development. Psychological Assessment, 7(3), 309-319.

Diamantopoulos, A., \& Winklhofer, H.M. (2001). Index construction with formative indicators: An alternative to scale development. Journal of Marketing Research, 38, 269-277.

Dijkstra, T.K., \& Henseler, J. (2015). Consistent Partial Least Squares Path Modeling. MIS Quarterly, 39(2), 297-316.

Ekinci, Y., Sirakaya-Turk, E., \& Preciado, S. (2013). Symbolic consumption of tourism destination brands. Journal of Business Research, 30(2), 10-15.

Fornell, C., \& Larcker, D.F. (1981). Evaluating structural equations models with unobservable variables and measurement error. Journal of Marketing Research, 18, 39-50. 
Fornell, C. (1982). A second generation of multivariate analysis: An overview. In Fornell, C. (Ed.): A second Generation of Multivariate Analysis (vol. 1) (pp. 1-21). New York: Praeger Publishers.

Gallegos, O. \& López-López. A. (2004). Turismo y estructura territorial en Ciudad Juárez, México, Investigaciones Geográficas (Boletín del Instituto de Geografía, UNAM), 53, 141-162.

Geisser, S. (1975). The predictive simple reuse method with applications. Journal of the American Statistical Association, 70 (350), 320-328.

Gelbman, A., \& Timothy, D.J. (2011). Border complexity, tourism and international exclaves. A case study. Annals of Tourism Research, 38(1), 110-131.

Gold, A. H., Malhotra, A., \& Segars, A. (2001). Knowledge Management: An Organizational Capabilities Perspective. Journal of Management Information Systems, 18(1), 185-214.

Gursoy, D., McCleary, K. W., \& Lepsito, L. R. (2007). Propensity to complain: Affects of personality and behavioral factors. Journal of Hospitality \& Tourism Research, 31(3), 358-386.

Hageman, K., Berger, S., Gemie, S., \& Williams, C. (2004) Creating and Crossing Borders: The State, Future and Quality of Border Studies. Glamorgan: University of Glamorgan, Wales.

Hair, J.F., Hult, G.T., Ringle, C. M., \& Sarstedt, M. (2017). A primer on partial least squares structural equation modeling (PLS-SEM). Thousand Oak: Sage.

Hair, J.F., Sarstedt, M., Hopkins, L., \& Kuppelwieser, V. (2014). Partial Least Squares structural equation modeling (PLS-SEM). An emerging tool in business research. European Business Review, 26(2), 106-121.

Hair, J.F., Sarstedt, M., Ringle, C.M. \& Mena, J.A. (2012). An assessment of the use of partial least squares structural equation modeling in marketing research. Journal Of The Academy of Marketing Science, 4O(3), 414-433.

Han, H., \& Kim, Y., (2010). An investigation of green hotel customers' decision formation: developing and extended model of the theory of planned behavior. International Journal of Hospitality Management, 29(4), 659-668.

Henseler, J., Hubona, G., \& Ray, P.A. (2016). Using PLS path modeling in new technology research: updated guidelines. IMDS, 116(1), 2-20.

Henseler, J., Ringle, C.M., \& Sinkovics, R.R. (2009). The use of partial least squares path modeling in international maketing. Advances in International Marketing, 20, 277-319.

Hernández Maestro, R.M., Muñoz Gallego, P.A., \& Santos Requejo, L. (2006). The Moderating Role of Familiarity in Rural Tourism in Spain. Tourism Management, 28(4), 951-964.

Jimber del Río, J.A., Orgaz Agüera, F., Moral Cuadra, S. \& Cañero Morales, S. (2017). Satistaction in border Tourism: an analysis with structural equations. European Research on Management and Business Economics, 23(2), 102-112.

Kline, R.B. (2011). Principles and practice of structural equation modelling. (3rd Edition). New York: Guildford Press.

Lacoste, Y. (1993): Dictionnaire de geopolitique. Paris. Flammarion.

Lee, C. K., Yoon, Y. S., \& Lee, S. K. (2007). Investigating the relationships among perceived value, satisfaction, and recommendations: The case of the Korean DMZ. Tourism Management, 28(2), 204-214.

Lee, J., Lee, C.-K., \& Choi, Y. (2011). Examining the role of emotional and functional values in festival evaluation. Journal of Travel Research, 50, 685-696.

Lee, T. H. (2009). A structural model to examine how destination image, attitude, and motivation affect the future behavior of tourists. Leisure Sciences, 31, 215-236.

Long Range Planning. (2012). Partial least squares: The better approach to structural equation modeling? Long Range Planning (5), 312-319.

López-Guzmán, T., Torres Naranjo, M., Pérez-Gálvez, J.C., \& Carvache Franco, W. (2018). Gastronomic perception and motivation of a touristic destination: the city of Quito, Ecuador. GeoJournal of Tourism and Geosite, 21(1), 61-73.

Martín-Ruíz, D., Castellanos-Verdugo, M., \& Oviedo-García, M.A. (2010). A visitors' evaluation index for a visit to an archeological site. Tourism Management, 31(5), 590-596.

Mason, M. C., \& Nassivera, F. (2013). A conceptualization of the relationships between quality, satisfaction, behavioral intention, and awareness of a festival. Journal of Hospitality Marketing \& Management, 22(2), 162-182.

Mathieson, K., Peacock, E., \& Chin, W.W. (2001). Extending the technology acceptance model: the influence of perceived user resources. The database for advancees in Information Systems, 32(3), 86-112.

Mattila, A.S (2001). The impact of relationship type on soncumer loyalty in a context of service failure. Journal of Service Research, 4(2), 91-101.

Millán, A., \& Esteban, A. (2004). Development of a multiple-itemscale for measuring customer satisfaction in travel agencies services. Tourism Management, 25(5), 533-546.

Mohd-Any, A. A., Winklhofer, H., \& Ennew, C. (2015). Measuring users' value experience on a travel website (evalue): What value is cocreated by the user? Journal of Travel Research, 54(4), 496-510.

Moliner Velázquez, B., Gil Saura, I., \& Ruiz Molina, M.E. (2011). Conceptualizing and Measuring Loyalty: Towards a Conceptual Model of Tourist Loyalty Antecedents. Journal of Vacation Marketing, 17(1), 65-81.

Newman, D. (2006). The Lines that Continue to Separate Us: Borders in our 'Borderless' World. Progress in Human Geography, 3o(2), 143-161.

Nicholas, L.; Thapa, B. \& Ko, Y. (2009). Residents' perspectives of a World Heritage site - The Pitons Management Area, St. Lucia. Annals of Tourism Research, 36(3), 390-412.

Nunnally, J. (1978). Psychometric theory. New York: McGraw-Hill. 
Orgaz Agüera, F., \& López-Guzmán, T. (2015). Análisis del perfil, motivaciones y valoraciones de los turistas gastronómicos. El caso de la República Dominicana. ARA Journal, 5(1), 43-52.

Oviedo García, M.A., Castellanos Verdugo, M., Vega Vázquez, M. \& Orgaz-Agüera, F. (2016). The mediating roles of the overall perceived value of the ecotourism site and attitudes towards ecotourism through the key relationship ecotourism knowledge-ecotourism satisfaction. International Journal of Tourism Research, 19(2), 203-213.

Perkmann, M. (2003). Cross-border regions in Europe: significance and drivers of regional crossborder cooperation. European Urban and Regional Studies, 10(2), 153-171.

Petrick, J. F. (2004). The roles of quality, value and satisfaction in predicting cruise passengers' behavioral intentions. Journal of Travel Research, 42(4), 397-407.

Pike, S., Bianchi, C., Kerr, G., \& Patti, C. (2010). Consumer-based brand equity for Australia as a long-haul tourism destination in an emerging market. International Marketing Review, 27, 434-449.

Prayag, G., \& Ryan, C. (2012). Antecedents of tourists' loyalty to Mauritius: The role and influence of destination. Journal of Travel Research, 51(3), 342-356.

Prebensen, N. K., Kim, H., \& Uysal, M. S. (2016). Co-creation as moderator between the experience value and satisfaction relationship. Journal of Travel Research, 5(7), 934-945.

Prebensen, N.K., Woo, E., \& Uysal, M.A. (2014). Experience value: antecedents and consecuences. Current Issues in Tourism, $17(10)$, 910-928.

Roberts, N., \& Thatcher, J. (2009). Conceptualizing and testing formative constructs: Tutorial and annotated example. ACM SIGMIS Database, 4O(3), 3-39.

Rogerson, C.M., \& Rogerson, J.M. (2019). Tourism in South Africa's borderland regions: a spatial view. GeoJournal of Tourism and Geosite, 24(1), 175-188.

Roldán, J.L., \& Sánchez-Franco, M.J. (2012). Variance-based structural equation modeling: guidelines for using partial least squares in information systems research. In: Mora, M., Gelman, O., Steenkamp, A., Raisinghani, M.S. (Eds.), Research Methodologies, Innovations and Philosophies in Software Systems Engineering and Information Systems (pp. 193-221). IGI Group, Hershey.

Rundle-Thiele, S. (2005). Exploring loyal qualities: assessing survey-based loyalty measures. Journal of Services Marketing, 19(7), 492-500.

Ryu, K., Han, H., \& Kim, T. H. (2008). The relationships among overall quick-casual restaurant image, perceived value, customer satisfaction, and behavioral intentions. International Journal of Hospitality Management, 27(3), 459-469.

Schmitt-Egner, P. (1998). Grenzüberschreitende Zusammenarbeit. In G. Brunn and P. Schmitt- Egner (eds), Europa als Gegenstand wissenschaftlicher Forschung und Strategie transnationaler Praxis. Anmerkungen zur Theorie, Empirie und Praxis des transnationalen Regionalismus in Grenzüberschreitende Zusammenarbeit in Europa (pp. 27-77). Baden-Baden: Nomos

Sofield, T. H. B. (2006). Border tourism and border communities: An overview. Tourism Geographies, 8(2), $102-121$.

Studzieniecki, T., Palmowski, T., \& Korneevets, V. (2016). The system of cross-border tourism in the PolishRussian borderland. Procedia, 39, 545-552.

Sullivan, P., Bonn, M.A., Bhardwaj, V., \& Dupont, A. (2012). Mexican national crossborder shopping: exploration of retail tourism. Journal of Retailing and Consumer Services, 19, 596-604.

Teo, T.S.H., Srivastava, S.C., \& Jiang, L. (2008). Trust and electronic government success: An empirical study. Journal of Management Information Systems, 25(3), 99-132.

Tian-Cole, S., Crompton, J. L., \& Willson, V. L. (2002). An empirical investigation of the relationships between service quality, satisfaction and behavioral intentions among visitors to a wildlife refuge. Journal of Leisure Research, 34(1), 1-24.

Valenzuela Arce, J.M. (2003). Por las fronteras del norte. Una aproximación cultural a la frontera MéxicoEstados Unidos. México: Fondo de Cultura Económico.

Werts, C.E., Linn, R.L. \& Jöreskog, K.G. (1974). Interclass reliability estimates: testing structural assumptions. Educational and Psychological Measurement, 34, 25-33.

Williams, P., \& Soutar, G.N. (2009). Value, satisfaction and behavioral intentions in an adventure tourism context. Annals of Tourism Research, 36(3), 413-438.

Wurzinger, S., \& Johansson, M. (2006). Environmental concern and knowledge of ecotourism among three groups of Swedish tourists. Journal of Travel Research, 45(November), 217-226.

Yoon, Y., Lee, J., \& Lee, C. (2010). Measuring festiva quality and value affecting visitors' satisfaction and loyalty using structural approach". Internation Journal in Hospitality Management, 29(2), 335-342.

Yüksel, A., \& Yüksel, F. (2007). Shopping Risk Perceptions: Effects on tourists' emotions, satisfaction and expressed loyalty intentions. Tourism Management, 28(3), 703-713.

Zhang, H. \& Lai Lei, S. (2012). A structural model of residents' intention to participate in ecotourism: The case of a wetland community. Tourism Management, 33(4), 916-920.

*** UNWTO (2017). UNWTO Tourism Highlights, 2017 Edition. Madrid, Spain: World Tourism Organization.

Submitted:

27.02.2019
Revised:

03.07.2019
Accepted and published online 26.07.2019 